\title{
AGE VARIATIONS AND SEXUAL DIMORPHISM IN ADIPOSITY AND BODY COMPOSITION AMONG TRIBAL ADOLESCENTS OF KHARAGPUR, WEST BENGAL, INDIA
}

DOI: $\underline{\text { http://doi.org/10.26758/11.1.5 }}$

Gopal Chandra MANDAL (1), Saheli BISWAS (2), Pijush Kanti ROY (2), Kaushik BOSE (2)

(1) Bangabasi College, Kolkata, India;

(2) Vidyasagar University, Paschim Midnapore, West Bengal, India

Address correspondence to: Gopal Chandra Mandal, Department of Anthropology, Bangabasi College, 19, Rajkumar Chakraborty Sarani, Kolkata-700009, India, Ph.: 91-9433773205; E-mail: golmal_anth@rediffmail.com

\begin{abstract}
Objectives. Although tribals constitute around $8.6 \%$ of the total population of India, detailed information on their body composition is scanty. Thus, our objective was to evaluate age variations and sexual dimorphism in adiposity and body composition among rural tribal adolescents of Kharagpur, West Bengal, India.

Material and methods. This cross-sectional study was conducted among 788 tribal adolescent boys and girls, aged 10-17 years of Kharagpur, West Midnapore, West Bengal, India. Height (kg), weight $(\mathrm{cm})$ and skinfolds were measured following standard method. The Body Mass Index (BMI) was derived. Body composition measures including Percent Body Fat (PBF), Fat Mass (FM), Fat Free Mass (FFM), Fat Mass Index (FMI) and Fat Free mass Index (FFMI) were computed using standard equations.

Results. All the variables showed a significant age trend in both sexes. Age-combined significant sex differences existed in mean BMI and all body composition measures. Girls had significantly higher mean values of fat measures (PBF, FM and FMI) whereas boys had significantly higher mean values of non-fat measures (FFM and FFMI). In both sexes, age had significant correlations with BMI and the five body composition measures. Similarly, all body composition indicators were significantly correlated with BMI in both sexes.

Conclusions. There were significant age and sex variations in body composition measures. Girls had significantly more fat mass whereas boys had more lean body mass. All body composition measures increased significantly with increasing age as well as BMI. Attainment of puberty could be a mediating factor causing these age variations and sexual dimorphism.
\end{abstract}

Keywords: India, tribal adolescents, age variations, sexual dimorphism, body composition.

\section{Introduction}

The adiposity of an individual can be assessed by body composition. Eveleth and Tanner (1990) commented that, the age, sex, genetic component, environmental conditions affect the differential accumulation of body fat which is considered as a good indicator of the health and nutritional status of a community. Skinfold thickness is an important measure of fatness (Roche, Sievogel, Chumlea, \& Webb, 1981). Body mass index (BMI) has been found to be associated with body composition (Garrow \& Webster, 1985) and nutritional status. It also has a high correlation with body fatness (Rolland-Cachera, 1993). The influence of body fat distribution on health, first suggested by Vague in 1956, is a topic of current interest. Several criteria are used for selecting 
probable measures for nutritional studies. Skinfold thickness measures subcutaneous or "low-risk" fat and is thus better for measuring body composition, while BMI is good for assessing the relationship between internal fat and risk factors (Rolland-Cachera, 1993). Skinfold thickness has been measured to estimate total body fat (TBF) and provide a fair assessment of the fat location. Nearly all of the fat in the body lies beneath the skin, so thickness of subcutaneous fat reflects body fat (Orphanidou, 1994). As the subcutaneous fat serves as a reservoir of energy during nutritional deprivation, lower BF indicates a lower energy intake by children. The role of environment in the development of adiposity is also evidenced in USA (Troiano, Flegal, Kuczmarski, Campbell, \& John, 1995) and some developing countries (Martorell, Kettel Khan, Hughes, \& Grummer-Strawn, 2000). In very poor countries, such as those in Sub-Saharan Africa and South Asia, obesity among women was greatly concentrated in an urban environment and among better educated women, whereas in more developed regions, obesity levels were more equally distributed in the general population. The distribution of BMI and subcutaneous fat in children of different ethnic origins - African or Indian subcontinent descent living in Trinidad and Tobago, was studied by Gulliford, Mahabir, Rocke and Chinn (2001). A study among young people of Romania by Rada (2017) pointed out that although sedentary life was high among girls, boys showed higher rates of overweight and obesity and opined that it may be due to the diet practices among girls.

According to Must and Anderson (2006), although BMI is frequently used to evaluate obesity among children, it has its limitations like, there is no possibility to differentiate obesity due to fat mass (FM) from that due to excess lean body mass. It is important to assess body composition continuously and accurately during infancy which will help to evaluate the weight gained overtime. Furthermore, it also provides useful information on nutritional requirements, the efficacy of diet and medical interventions, and the influence of chronic diseases (Olhager \& Forsum, 2003). The global prevalence of overweight and obesity among children increased from $4.2 \%$ in 1990 to $6.7 \%$ in 2010 and is expected to reach $9.1 \%$ by 2020 (de Onis, Blössner, \& Borghi, 2010). The major patterns of fat distribution develop in childhood and adolescence in both sexes. Males develop more trunk fat than females, and this development is more clearly established after puberty (Bray \& Bouchard, 1988). Children and adolescents with a high BMI also tend to have a high level of body fatness, but because BMI is based only on weight and height, it can be an inaccurate indicator of body fatness, particularly among those who have normal or relatively low levels of body fatness (Bray, DeLany, Volaufova, Harsha, \& Champagne, 2002). Many authors pointed out that relation of BMI to body fatness differs based on race-ethnicity groups (Deurenberg, Deurenberg-Yap, Foo, Schmidt, \& Wang, 2003; Freedman et al., 2008). Asians generally have more body fat and blacks have less body fat than white Caucasians. Although, Ulijaszek and Kerr (1999) commented about the technical error of measurements related with skinfold thicknesses, these are being widely used among children and adolescents as they provide a more direct and accurate estimate of body fatness than BMI (Laurson, Eisenmann, \& Welk, 2011; Leitao, Rodrigues, Neves, \& Carvalh, 2011; Going et al., 2011). Furthermore, many authors are of opinion that, there is stronger association of body fatness with skinfold thicknesses than with BMI (Bray et al., 2002; Sardinha, Going, Teixeira, \& Lohman, 1999; Steinberger et al., 2005; Freedman et al., 2007). In a study among children and adolescents aged 7 15 years from Vojvodina, North Serbia, it was reported that percent of skeletal muscle mass (\% SMM) increased with age in both sexes and was significantly influenced by gender, age and physical activity, cumulatively and partially (Pavlica \& Rakic, 2019). The role of physical activity in body composition had also been investigated in another study (Nikolova, Mladenova, Boyadzhiev, \& Paskaleva, 2019) among 7-17 years aged children and adolescents from Plovdiv, Bulgaria. The authors had observed that the increase in percentage body fat and values of the fat mass index and the decrease in frame index were entirely or partially caused by reduced physical activity. Albu and Rada (2014) had studied in detail the dynamics of anthropological markers among Romanian teenagers between 19781999. They had found significant changes in anthropometry and body composition in this time span. 
Adolescence is one of the four known sensitive periods in life for the development of obesity, the other three being intrauterine life, infancy and ages 5-7 years (Monyeki, van Lenthe, \& Steyn, 1999). It begins with pubescence, the earliest signs of emergence of secondary sexual characters and continues up to the morphological and physiological maturation to the adult status (WHO, 1995). Unique changes that occur in an individual during this period are accompanied by progressive achievement of biological maturity (Tanner, 1962). This period is very crucial since these are the formative years in the life of an individual when major physical, psychological and behavioural changes take place (Patil, Wasnik, \& Wadke, 2009).

There are several socially disadvantaged communities in India, among which tribal populations are the most deprived ones. Although, tribals constitute around $8.6 \%$ of the total population of India, detailed information on their body composition is scanty (Khadilkar \& Khadilkar, 2019). In this context, we have tried to investigate age variations and sexual dimorphism of body composition of the tribals of a particular area of Eastern India.

In this context, our objective was to evaluate age variations and sexual dimorphism in adiposity and body composition among rural tribal adolescents of Kharagpur, West Bengal, India.

\section{Material and methods}

Area under study. The present cross-sectional study was conducted in Higher Secondary Schools of 10 villages (Changual, Gangarampur, Benapur, Balarampur, Sankoa, Gopinathpur, Chakmakrampur, Mawa, Amlatoria, Chakturia) of Kharagpur Community Development Block II, West Midnapore, West Bengal, India which are situatedaround10 km from Midnapore town, the district head quarter. A total of $25.6 \%$ of the total population of the Block is constituted by tribal groups.

The participants. Measurements as well as other information were collected from 788 tribal adolescents (370 boys; 418 girls), aged 10-17 years. The students who were present in class were randomly selected. Various tribal communities like Santhal, Bhumij, Munda, Mahali, Sabar live in these villages. The living amenities were more or less same for all the groups. Hence, we considered them as a single homogenous population termed 'tribal group'. Age of the participants was calculated from the Date of Birth recorded in the school registration books. Adolescents of non-tribal communities were excluded from this study. Table 1 represents the age and sex wise distribution of the participants.

\section{Table 1}

Distribution of the participants by age and sex

\begin{tabular}{llllllllll}
\hline Sex & \multicolumn{8}{c}{ Age in years } & Total \\
\cline { 2 - 8 } & 10 & 11 & 12 & 13 & 14 & 15 & 16 & 17 & \\
\hline Boys & 55 & 42 & 54 & 52 & 43 & 39 & 45 & 40 & 370 \\
Girls & 40 & 48 & 64 & 58 & 50 & 57 & 52 & 49 & 418 \\
Total & 95 & 90 & 118 & 110 & 93 & 96 & 97 & 89 & 788 \\
\hline
\end{tabular}

Anthropometric variables. Height $(\mathrm{kg})$, weight $(\mathrm{cm})$, triceps skinfold (TRSF, mm) and subscapular skinfold (SSSF, mm) were measured following standard methods (Lohman, Roche, \& Martorell, 1988) by the second and third (SB and PKR) authors. Skinfold measurements were used to measure $\mathrm{BF}(\%)$ from which fat mass $(\mathrm{FM}, \mathrm{kg}$ ) and fat-free mass (FFM, $\mathrm{kg}$ ) were calculated. Triceps (TRSF, $\mathrm{mm}$ ) and subscapular (SSSF, $\mathrm{mm}$ ) skinfold thicknesses were measured to the nearest $0.1 \mathrm{~mm}$ using Holtain skinfold caliper. The following measures were derived: BMI, Percent Body Fat 
(PBF), Fat Mass (FM), Fat Free Mass (FFM), Fat Mass Index (FMI) and Fat Free Mass Index (FFMI).The equations used are presented in Table 2.

\section{Table 2}

BMI and body composition variables

\begin{tabular}{lcl}
\hline \multicolumn{1}{c}{ Variables } & Formulae & \multicolumn{1}{c}{ Reference } \\
\hline BMI & Weight $(\mathrm{kg}) /$ Height $(\mathrm{m})^{2}$ & WHO, 1995 \\
PBF $($ Boys $)$ & $1.21(\mathrm{TRSF}+\mathrm{SSSF})-0.008(\mathrm{TRSF}+\mathrm{SSSF})^{2}-1.7$ & Slaughter et al., 1988 \\
PBF $($ Girls $)$ & $1.33(\mathrm{TRSF}+\mathrm{SSSF})-0.013(\mathrm{TRSF}+\mathrm{SSSF})^{2}-2.5$ & \\
FM $(\mathrm{kg})$ & Body Weight $(\mathrm{kg}) \mathrm{x}[\mathrm{PBF} / 100]$ & \\
FFM $(\mathrm{kg})$ & Weight $(\mathrm{kg})-$ Fat Mass $(\mathrm{kg})$ & Van Itallie, Yang, \\
FMI $\left(\mathrm{kg} / \mathrm{m}^{2)}\right.$ & FM $(\mathrm{kg}) / \mathrm{Height}{ }^{2}\left(\mathrm{~m}^{2}\right)$ & Heymsfield, Funk, \& \\
FFMI $\left(\mathrm{kg} / \mathrm{m}^{2)}\right.$ & Fat Free Mass $(\mathrm{kg}) / \mathrm{Height}^{2}\left(\mathrm{~m}^{2}\right)$ & Boileau, 1990 \\
\hline
\end{tabular}

The technical error of measurements (TEM) was calculated for height and weight and they were found to be within reference values as given by Ulijaszek and Kerr (1999). Thus, TEM were not incorporated in any analyses.

Statistical analyses. Students't-test and ANOVA were performed to study sexual dimorphism and age variations, respectively. Pearson's correlation coefficient (r) analyses was undertaken to study the association between the continuous variables. All statistical analyses were performed using statistical package for social sciences (SPSS, version 16.0).

Ethical approval. Ethical approval was obtained from Department of Anthropology, Vidyasagar University. Permission for conducting this study was also obtained from each school authority. Moreover, informed verbal consent was obtained from each participant.

\section{Results}

In case of PBF, among boys the mean values didn't show gradual increase with age. However, there was the gradual increase among girls and these values were much higher at all ages than in boys (Figure 1). Although the sex differences were significant in most of the cases (except at few ages) for FM, FFM, FMI and FFMI, both sexes showed an increasing trend with age. In case of FM the mean values were higher among girls in all age groups, whereas, FFM displayed a reverse trend (Figure 2). When age combined overall means were taken into account, except height, FFM and FFMI, all other variables showed higher means among girls. All the variables showed significant sexual dimorphism in each of the age groups but it was different in BMI, where it was significant in case of only 14 and 15 years of age.

Figure 1 shows that there was a gradual increase of PBF among girls and these values were much higher at all ages. 


\section{Figure 1}

Age specific sex variation in PBF

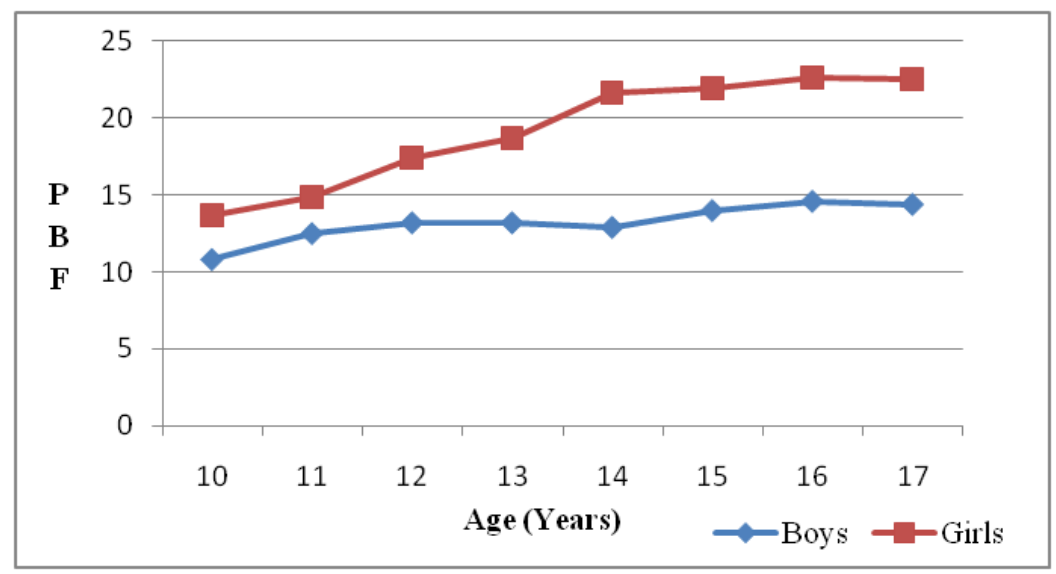

Figure 2 shows a reverse trend compared to the previous figures with boys having higher values from age 13 onwards.

\section{Figure 2}

\section{Age specific sex variation in FFM}

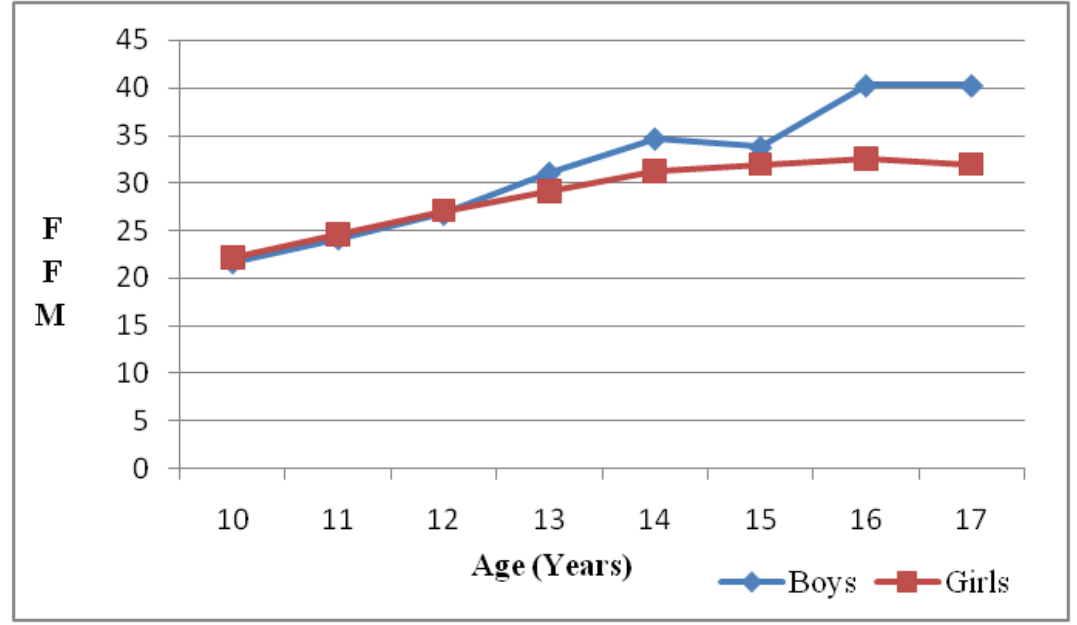

Table 3 presents the age and sex-specific mean height, weight, BMI and the five body composition measures. The mean values of all the variables significantly $(p<0.001)$ increased with age. In case of height and weight, the mean values were lower among boys in earlier ages which were reversed in the later ages. This was indicative of probably an earlier occurrence of adolescent growth spurt among girls. 


\section{Table 3}

Age and sex-specific mean height, weight, BMI and the five body composition measures

\begin{tabular}{|c|c|c|c|c|c|c|c|c|c|c|c|}
\hline \multirow[t]{2}{*}{ Variables } & \multirow[t]{2}{*}{ Sex } & \multicolumn{8}{|c|}{ Age in years } & \multirow[t]{2}{*}{ Total } & \multirow[t]{2}{*}{$F$} \\
\hline & & 10 & 11 & 12 & 13 & 14 & 15 & 16 & 17 & & \\
\hline \multirow{3}{*}{$\begin{array}{l}\text { Height } \\
(\mathrm{cm})\end{array}$} & Boys & $\begin{array}{l}131.0 \\
(7.5)\end{array}$ & $\begin{array}{l}135.6 \\
(6.01)\end{array}$ & $\begin{array}{c}140.5 \\
(8.4)\end{array}$ & $\begin{array}{l}147.7 \\
(7.6)\end{array}$ & $\begin{array}{l}152.9 \\
(10.7)\end{array}$ & $\begin{array}{c}152.9 \\
(9.3)\end{array}$ & $\begin{array}{l}160.3 \\
(6.6)\end{array}$ & $\begin{array}{l}160.4 \\
(7.6)\end{array}$ & $\begin{array}{l}146.8 \\
(13.1)\end{array}$ & $87.9 * * *$ \\
\hline & Girls & $\begin{array}{l}133.7 \\
(8.3)\end{array}$ & $\begin{array}{l}139.1 \\
(6.6)\end{array}$ & $\begin{array}{c}144.2 \\
(7.2)\end{array}$ & $\begin{array}{l}145.9 \\
(6.5)\end{array}$ & $\begin{array}{c}148.7 \\
(5.7)\end{array}$ & $\begin{array}{c}149.9 \\
(4.6)\end{array}$ & $\begin{array}{c}150.4 \\
(5.3)\end{array}$ & $\begin{array}{c}150.9 \\
(5.2)\end{array}$ & $\begin{array}{c}145.7 \\
(8.2)\end{array}$ & $43.9 * * *$ \\
\hline & $t$ & -1.7 & $-2.6^{*}$ & $-2.6^{*}$ & 1.3 & $2.4^{*}$ & $2.2^{*}$ & $8.2 * * *$ & $7.1 * * *$ & 1.5 & \\
\hline \multirow{3}{*}{$\begin{array}{l}\text { Weight } \\
(\mathrm{kg})\end{array}$} & Boys & $\begin{array}{l}24.4 \\
(4.3)\end{array}$ & $\begin{array}{l}27.8 \\
(5.2)\end{array}$ & $\begin{array}{l}31.1 \\
(6.5)\end{array}$ & $\begin{array}{l}36.0 \\
(6.2)\end{array}$ & $\begin{array}{l}40.0 \\
(7.0)\end{array}$ & $\begin{array}{l}39.4 \\
(8.1)\end{array}$ & $\begin{array}{l}47.4 \\
(8.0)\end{array}$ & $\begin{array}{l}47.2 \\
(7.0)\end{array}$ & $\begin{array}{c}36.1 \\
(10.3)\end{array}$ & $78.5 * * *$ \\
\hline & Girls & $\begin{array}{l}25.8 \\
(5.3)\end{array}$ & $\begin{array}{l}29.1 \\
(5.7)\end{array}$ & $\begin{array}{l}32.9 \\
(6.0)\end{array}$ & $\begin{array}{l}36.0 \\
(6.0)\end{array}$ & $\begin{array}{l}40.2 \\
(6.5)\end{array}$ & $\begin{array}{l}41.1 \\
(4.1)\end{array}$ & $\begin{array}{l}42.4 \\
(6.2)\end{array}$ & $\begin{array}{l}41.4 \\
(5.1)\end{array}$ & $\begin{array}{l}36.4 \\
(7.9)\end{array}$ & $57.9 * * *$ \\
\hline & $t$ & -1.40 & -1.16 & -1.56 & -0.02 & -0.2 & -1.4 & $3.5^{* *}$ & $4.5^{* * *}$ & -0.5 & \\
\hline \multirow[t]{3}{*}{ BMI } & Boys & $\begin{array}{l}14.1 \\
(1.4)\end{array}$ & $\begin{array}{l}15.0 \\
(1.9)\end{array}$ & $\begin{array}{l}15.6 \\
(2.0)\end{array}$ & $\begin{array}{l}16.4 \\
(2.1)\end{array}$ & $\begin{array}{l}17.1 \\
(2.4)\end{array}$ & $\begin{array}{l}16.8 \\
(2.6)\end{array}$ & $\begin{array}{l}18.4 \\
(2.2)\end{array}$ & $\begin{array}{l}18.3 \\
(2.0)\end{array}$ & $\begin{array}{l}16.3 \\
(2.5)\end{array}$ & $24.4 * * *$ \\
\hline & Girls & $\begin{array}{l}14.3 \\
(1.9)\end{array}$ & $\begin{array}{l}14.9 \\
(2.2)\end{array}$ & $\begin{array}{l}15.7 \\
(1.9)\end{array}$ & $\begin{array}{l}16.8 \\
(2.1)\end{array}$ & $\begin{array}{l}18.1 \\
(2.4)\end{array}$ & $\begin{array}{l}18.3 \\
(1.9)\end{array}$ & $\begin{array}{l}18.7 \\
(2.2)\end{array}$ & $\begin{array}{l}18.2 \\
(2.0)\end{array}$ & $\begin{array}{l}16.9 \\
(2.6)\end{array}$ & $32.5 * * *$ \\
\hline & $t$ & -0.54 & 0.17 & -0.29 & -1.0 & $-2.1 *$ & $-3.4 * *$ & -0.7 & 0.21 & $-3.3 * *$ & \\
\hline \multirow[t]{3}{*}{ PBF } & Boys & $\begin{array}{l}10.8 \\
(2.6)\end{array}$ & $\begin{array}{l}12.5 \\
(4.6)\end{array}$ & $\begin{array}{l}13.2 \\
(4.5)\end{array}$ & $\begin{array}{l}13.2 \\
(4.3)\end{array}$ & $\begin{array}{l}12.9 \\
(3.3)\end{array}$ & $\begin{array}{l}14.0 \\
(4.0)\end{array}$ & $\begin{array}{l}14.6 \\
(4.1)\end{array}$ & $\begin{array}{l}14.4 \\
(3.9)\end{array}$ & $\begin{array}{l}13.1 \\
(4.1)\end{array}$ & $4.7 * * *$ \\
\hline & Girls & $\begin{array}{l}13.7 \\
(3.9)\end{array}$ & $\begin{array}{l}14.9 \\
(3.8)\end{array}$ & $\begin{array}{l}17.4 \\
(3.9)\end{array}$ & $\begin{array}{l}18.7 \\
(4.4)\end{array}$ & $\begin{array}{l}21.6 \\
(4.7)\end{array}$ & $\begin{array}{l}21.9 \\
(3.6)\end{array}$ & $\begin{array}{l}22.6 \\
(4.0)\end{array}$ & $\begin{array}{l}22.5 \\
(3.8)\end{array}$ & $\begin{array}{l}19.3 \\
(5.1)\end{array}$ & $37.6^{* * * *}$ \\
\hline & $t$ & $\begin{array}{l}4.5 \\
* * *\end{array}$ & $2.7 * *$ & $-5.0 * *$ & $\begin{array}{l}-6.6 \\
* * *\end{array}$ & $\begin{array}{c}-10.3 \\
* * *\end{array}$ & $\begin{array}{c}-10.1 \\
* * *\end{array}$ & $\begin{array}{l}-9.7 \\
* * *\end{array}$ & $\begin{array}{c}-10.0 \\
* * *\end{array}$ & $\begin{array}{c}-18.5 \\
* * *\end{array}$ & \\
\hline \multirow[t]{3}{*}{ FM } & Boys & $\begin{array}{c}2.7 \\
(1.0)\end{array}$ & $\begin{array}{c}3.6 \\
(2.3)\end{array}$ & $\begin{array}{c}4.3 \\
(2.5)\end{array}$ & $\begin{array}{c}4.9 \\
(2.4)\end{array}$ & $\begin{array}{c}5.2 \\
(1.9)\end{array}$ & $\begin{array}{c}5.6 \\
(2.6)\end{array}$ & $\begin{array}{c}7.1 \\
(3.03)\end{array}$ & $\begin{array}{c}6.9 \\
(2.9)\end{array}$ & $\begin{array}{c}4.9 \\
(2.7)\end{array}$ & $19.6^{* * *}$ \\
\hline & Girls & $\begin{array}{c}3.7 \\
(1.8)\end{array}$ & $\begin{array}{c}4.5 \\
(2.0)\end{array}$ & $\begin{array}{c}5.8 \\
(2.3)\end{array}$ & $\begin{array}{c}6.9 \\
(2.5)\end{array}$ & $\begin{array}{c}8.9 \\
(3.2)\end{array}$ & $\begin{array}{c}9.1 \\
(2.2)\end{array}$ & $\begin{array}{c}9.7 \\
(2.9)\end{array}$ & $\begin{array}{c}9.4 \\
(2.4)\end{array}$ & $\begin{array}{c}7.3 \\
(3.2)\end{array}$ & $45.0 * * *$ \\
\hline & $t$ & $-3.4 * *$ & -1.93 & $\begin{array}{l}-3.4 \\
* * *\end{array}$ & $\begin{array}{l}-4.3 \\
* * *\end{array}$ & $\begin{array}{l}-6.5 \\
* * *\end{array}$ & $\begin{array}{l}-7.2 \\
* * *\end{array}$ & $\begin{array}{l}-4.3 \\
* * *\end{array}$ & $\begin{array}{l}-4.5 \\
* * *\end{array}$ & $\begin{array}{l}-11.1 \\
* * *\end{array}$ & \\
\hline \multirow[t]{3}{*}{ FFM } & Boys & $\begin{array}{l}21.7 \\
(3.5)\end{array}$ & $\begin{array}{l}24.2 \\
(3.7)\end{array}$ & $\begin{array}{l}26.8 \\
(4.6)\end{array}$ & $\begin{array}{l}31.1 \\
(4.8)\end{array}$ & $\begin{array}{l}34.7 \\
(5.6)\end{array}$ & $\begin{array}{l}33.8 \\
(6.4)\end{array}$ & $\begin{array}{l}40.3 \\
(5.8)\end{array}$ & $\begin{array}{l}40.3 \\
(5.1)\end{array}$ & $\begin{array}{l}31.1 \\
(8.2)\end{array}$ & $92.7 * * *$ \\
\hline & Girls & $\begin{array}{l}22.1 \\
(3.8)\end{array}$ & $\begin{array}{l}24.6 \\
(4.1)\end{array}$ & $\begin{array}{l}27.1 \\
(4.1)\end{array}$ & $\begin{array}{l}29.1 \\
(3.9)\end{array}$ & $\begin{array}{l}31.3 \\
(3.8)\end{array}$ & $\begin{array}{l}32.0 \\
(2.7)\end{array}$ & $\begin{array}{l}32.6 \\
(3.8)\end{array}$ & $\begin{array}{l}32.0 \\
(3.4)\end{array}$ & $\begin{array}{l}29.1 \\
(5.0)\end{array}$ & $51.2 * * *$ \\
\hline & $t$ & -0.502 & -0.57 & -0.39 & $2.4^{*}$ & $3.5^{* *}$ & 1.9 & $7.9 * * *$ & 9.2 & $4.3 * * *$ & \\
\hline \multirow[t]{3}{*}{ FMI } & Boys & $\begin{array}{c}1.5 \\
(0.5)\end{array}$ & $\begin{array}{c}1.9 \\
(1.1)\end{array}$ & $\begin{array}{c}2.1 \\
(1.1)\end{array}$ & $\begin{array}{c}2.2 \\
(1.1)\end{array}$ & $\begin{array}{c}2.2 \\
(0.7)\end{array}$ & $\begin{array}{c}2.4 \\
(1.0)\end{array}$ & $\begin{array}{c}2.7 \\
(1.1)\end{array}$ & $\begin{array}{c}2.7 \\
(1.0)\end{array}$ & $\begin{array}{c}2.2 \\
(1.0)\end{array}$ & $7.5 * * *$ \\
\hline & Girls & $\begin{array}{c}2.0 \\
(0.9)\end{array}$ & $\begin{array}{c}2.3 \\
(0.9)\end{array}$ & $\begin{array}{c}2.7 \\
(0.9)\end{array}$ & $\begin{array}{c}3.2 \\
(1.1)\end{array}$ & $\begin{array}{c}4.0 \\
(1.4)\end{array}$ & $\begin{array}{c}4.1 \\
(1.0)\end{array}$ & $\begin{array}{c}4.3 \\
(1.2)\end{array}$ & $\begin{array}{c}4.1 \\
(1.0)\end{array}$ & $\begin{array}{c}3.4 \\
(1.3)\end{array}$ & $34.8 * * *$ \\
\hline & $t$ & $-3.3 * *$ & -1.61 & $-3.3 * *$ & $\begin{array}{l}-4.5 \\
* * *\end{array}$ & $\begin{array}{l}-7.6 \\
* * *\end{array}$ & $\begin{array}{l}-8.0 \\
* * *\end{array}$ & $\begin{array}{l}-6.7 \\
* * *\end{array}$ & $\begin{array}{l}-6.8 \\
* * *\end{array}$ & $\begin{array}{c}-13.6 \\
* * *\end{array}$ & \\
\hline \multirow[t]{3}{*}{ FFMI } & Boys & $\begin{array}{l}12.6 \\
(1.0)\end{array}$ & $\begin{array}{l}13.1 \\
(1.2)\end{array}$ & $\begin{array}{l}13.5 \\
(1.2)\end{array}$ & $\begin{array}{l}14.2 \\
(1.3)\end{array}$ & $\begin{array}{l}14.9 \\
(1.9)\end{array}$ & $\begin{array}{l}14.4 \\
(2.0)\end{array}$ & $\begin{array}{l}15.6 \\
(1.5)\end{array}$ & $\begin{array}{l}15.6 \\
(1.3)\end{array}$ & $\begin{array}{l}14.2 \\
(1.8)\end{array}$ & $29.2 * * *$ \\
\hline & Girls & $\begin{array}{l}12.3 \\
(1.2)\end{array}$ & $\begin{array}{l}12.7 \\
(1.4)\end{array}$ & $\begin{array}{l}13.0 \\
(1.2)\end{array}$ & $\begin{array}{l}13.6 \\
(1.1)\end{array}$ & $\begin{array}{l}14.1 \\
(1.3)\end{array}$ & $\begin{array}{l}14.3 \\
(1.1)\end{array}$ & $\begin{array}{l}14.4 \\
(1.3)\end{array}$ & $\begin{array}{l}14.1 \\
(1.3)\end{array}$ & $\begin{array}{l}13.6 \\
(1.4)\end{array}$ & $20.0 * * *$ \\
\hline & $t$ & 1.3 & 1.56 & $2.2 *$ & $2.5^{*}$ & $2.2^{*}$ & 0.43 & $4.4 * * *$ & $5.6 * * *$ & $5.0 * * *$ & \\
\hline
\end{tabular}

$*=\mathrm{p}<0.05 ; * *=\mathrm{p}<0.01 ; * * *=\mathrm{p}<0.001$

Sex specific correlations of age with BMI and the body composition measures are presented in Table 4. All the variables showed highly significant $(\mathrm{p}<0.01)$ positive correlations with age. All the fat measures (PBF, FM and FMI) displayed stronger correlations among girls. However in case of all the non-fat measures (FFM and FFMI) the trend was reverse, i.e. much higher correlations were noticed among boys. The sexual dimorphism was most marked in case of PBF followed by FMI. A noteworthy finding was that the BMI showed similar correlations in both sexes. 


\section{Table 4}

Sex specific correlation of age with BMI and body composition measures

\begin{tabular}{lcc}
\hline Variables & \multicolumn{2}{c}{$r$} \\
\cline { 2 - 3 } & Boys & Girls \\
\hline BMI & $0.553^{* *}$ & $0.561^{* *}$ \\
PBF & $0.260^{* *}$ & $0.600^{* *}$ \\
FM & $0.515^{* *}$ & $0.632^{* *}$ \\
FFM & $0.787^{* *}$ & $0.642^{* *}$ \\
FMI & $0.340^{* *}$ & $0.582^{* *}$ \\
FFMI & $0.582^{* *}$ & $0.464 * *$ \\
\hline
\end{tabular}

$* *=p<0.01$

Table 5 presents the sex specific correlations of BMI with the indicators of body composition. In both sexes, all the measures showed significant positive correlations ( $<<0.01)$ with BMI. It was observed that all the fat measures (PBF, FM and FMI) displayed much stronger associations with BMI in girls. The most noticeable sexual dimorphism was found in PBF.

\section{Table 5}

Sex specific correlation of BMI with the body composition measures

\begin{tabular}{ccc}
\hline Variables & \multicolumn{2}{c}{$r$} \\
\cline { 2 - 3 } & Boys & Girls \\
\hline PBF & $0.646^{* *}$ & $0.821^{* *}$ \\
FM & $0.833^{* *}$ & $0.901^{* *}$ \\
FFM & $0.779^{* *}$ & $0.839^{* *}$ \\
FMI & $0.810^{* *}$ & $0.923^{* *}$ \\
FFMI & $0.939^{* *}$ & $0.933^{* *}$ \\
\hline
\end{tabular}

$* *=\mathrm{p}<0.01$

\section{Discussions}

Adolescence is a decisive period of rapid physical growth attainment and development or maturity with multiple physiological changes occurring between the childhood and adulthood. It also includes body composition transforming with differential changes taking place between sexes (WHO, 1995; Wells, 2007).

Mean height and BMI of the present adolescents were much higher than the Santhal adolescent boys $(134.8 \mathrm{~cm}$ ) and (girls-142.8cm) respectively from Purulia, West Bengal (Das \& Bose, 2011). However, mean weight among boys and girls were similar (Das \& Bose, 2011). Mean height $(134.2 \mathrm{~cm})$ and weight $(29.9 \mathrm{~kg})$ among adolescent boys of Kolam tribe of Telengana (Karri, Ghritlahre, Das, \& Bose, 2017) state were much lower than our participants. A study among rural male adolescents from Naxalbari, Darjeeling District, West Bengal (Dey et al., 2011) found that the height $(154.4 \mathrm{~cm})$ and weight $(42.0 \mathrm{~kg})$ among boys were much higher than the participants of the present study. However, in comparison of the rural adolescent boys of West Bengal studied by Pal, Pari, Sinha and Dhara (2017), the mean values of the present adolescent boys were slightly lower for height and weight but these were slightly higher among the girls of the present study. Mean BMI among the boys was slightly higher than adolescent boys $\left(15.6 \mathrm{~kg} / \mathrm{m}^{2}\right)$ and slightly lower than found 
among girl $\left(17.4 \mathrm{~kg} / \mathrm{m}^{2}\right)$ Santhal adolescents from Purulia, West Bengal (Das \& Bose, 2011). Adolescent boys from Naxalbari, Darjeeling showed higher mean BMI $\left(17.7 \mathrm{~kg} / \mathrm{m}^{2}\right)$ than boys of the present study (Dey et al., 2011). Among the Rajbanshi adolescent girls from North Bengal, the three anthropometric variables had similar (to our study) mean values (Roy, Barman, Mondal, \& Sen, 2016).

The present study revealed that girls had higher mean PBF, FM and FMI than boys at all ages. A reverse sex trend was observed in case of FFM and FFMI. This indicated that the level of adiposity was significantly higher among girls. A similar trend has been reported in other studies from India as well as other countries also (Dutta Chowdhury, Chakraborti, \& Ghosh, 2007; Rakic \& Pavlica, 2014; Mandal \& Bose, 2017; Mehdad et al., 2012; Rajkumari, Akoijam, Akoijam, \& Longjam, 2012; Freedman, Horlick, \& Berenson, 2013; Nwizu, Njokanma, Okoromah, \& David, 2014; Sharma \& Mondal, 2018). Mean PBF among boys and girls of the present study were $2.8 \%$ and 3.9\% lower respectively, than those found among the adolescents from Imphal, Manipur, India (Rajkumari et al., 2012). In the same study, it was observed that FM was $3.8 \mathrm{~kg}$ higher among both the boys and girls than the participants of our study. A similar trend was also found among Moroccan adolescents aged 11-17 years, where, PBF among boys was 15.9\% higher and among girls it was $11.2 \%$ higher than our study (Mehdad et al., 2012). Similar results were observed in case of FM of the participants of the same study and school children from Washington, USA (Freedman et al., 2013). However, these were lower among Nigerian adolescents aged 10 - 18 years (Nwizu et al., 2014) and among school going children and adolescents from Phanshidewa Block, Darjeeling District, WB, India (Debnath, Mondal, \& Sen, 2018). Our study provided preliminary evidence of a significant spurt growth in PBF and FM. This indicated the approaching of peak velocities in height and weight (Bell, 1993). It is noteworthy to mention here that the role of height is more important than adiposity in predicting lean body mass (LBM or FFM) (Malina, Bouchard, \& Beunen, 1988).

Mean FFM of the adolescents of the present study increased gradually with age in both sexes. Sexual dimorphism became more pronounced at higher ages. The same trend had also been earlier reported among Nigerian adolescents. They showed more or less 30.0\% higher mean values among boys and girls (Nwizu et al., 2014). However, another recent study found that there were no significant sex differences among Santhal children (FFM: boys-22.2 kg; girls-21.2 kg) of Purulia, West Bengal, and their mean values were lower than the present study (Dutta Chowdhury et al., 2007).

The BMI was highly correlated with body composition parameters in both sexes and the magnitude was greater among girls (except in FFMI). Similar results had been earlier reported from Santhals of Purulia (Dutta Chowdhury et al., 2007), Moroccan adolescents (Mehdad et al., 2012), adolescents from Imphal, Manipur (Rajkumari et al., 2012), rural adolescent girls from Kabri Anglong, Assam (Sharma \& Mondal, 2018) and Chakmas of Tripura (Saha \& Sil, 2019). Maynard et al. (2001) in their analysis of the data from the Fels Longitudinal Study had also showed a significantly high correlation between BMI and body composition variables. Similar results had been reported from black Jamaican children (Gaskin \& Walker, 2003).

In the present study, the body composition measures that were significantly higher in girls indicated that they tend to accumulate more fat than boys. In our study, we derived body composition measures based on subscapular and triceps measurements. It has been earlier shown that girls possess higher adiposity in their subscapula and triceps regions (Zimmermann, Gübeli, Puntener, \& Molinari, 2004). The use of BMI to identify children with excess adiposity during the pubertal development has an important limitation; it has been shown that BMI increases in adolescents from both sexes are primarily determined by increases in FFM (or lean body mass, LBM) rather than in body fat compartment (Yoo, Lee, Kim, \& Sung, 2006). Pubertal ages are important for changing body composition and it is more marked earlier among girls between pre and menarche individuals (Prado Martinez, Marrodan Serrano, Acevedo Cantero, \& Carmenate Moreno, 2017). 
Besides demonstrating distinct age variations in both sexes, our study provided unequivocal evidence that there existed significant sexual dimorphism in body composition measures. We also found that, in girls, fat measures were more strongly associated with both age as well as BMI which is a measure of generalized obesity. The inverse was observed in boys, i.e. non-fat (or lean) body composition measures had a stronger relationship with age. Taken together, these results clearly indicated that with increasing age, there significantly more fat deposition among girls. Moreover, increase in BMI in girls is concomitant with increasing fat deposition. This implied that there was a distinct dimorphism in the increase between fat and non-fat (or lean) components with increasing BMI. These morphological changes could be mediated by the attainment of puberty. More detailed longitudinal studies are needed to fully comprehend the mechanism involved this significant sexual dimorphism in fat deposition. Unfortunately, the present investigation was cross sectional in nature which is major limitation of our study.

\title{
Conclusions
}

There were significant age and sex variations in body composition measures. Girls had significantly more fat mass whereas boys had more lean body mass. All body composition measures increased significantly with increasing age as well as BMI. Attainment of puberty, which involves hormonal changes, could be a mediating factor causing these age variations and sexual dimorphism. Further longitudinal studies are required to understand the mechanisms linked with these changes. The uniqueness of our study is that it deals with age variations and sexual dimorphism in body composition among tribals (indigenous people). Hitherto, to the best of our knowledge, such investigations are scanty from India.

\section{Conflict of interest: None}

\section{Acknowledgements}

All subjects who participated in the study are gratefully acknowledged. Special thanks are due to the parents and the School authorities for their kind cooperation and help.

\section{Funding}

The authors received no financial support for the research, authorship, and/or publication of this article.

\author{
Abbreviations used \\ SSSF - Sub scapular skinfold \\ TRSF - Triceps skinfold \\ BMI - Body mass index \\ FM -Fat Mass \\ FFM - Fat free mass (also known as Lean Body Mass, LBM) \\ FMI - Fat mass index \\ FFMI - Fat free mass index \\ PBF - Percent body fat
}




\section{References}

1. Albu, A., \& Rada, C. (2014). The dynamics of anthropological markers among Romanian teenagers between 1978-1999. Annuaire Roumain d'Anthropologie, 51, 65-73.

2. Bell, W. (1993). Body size and shape: a longitudinal investigation of active and sedentary boys during adolescence. Journal of Sports Science, 11, 127-138. doi: 10.1080/02640419308729976.

3. Bray, G. A., \& Bouchard, C. (1988). Role of fat distribution during growth and its relationship to health. American Journal of Clinical Nutrition, 47(3), 551-552.

4. Bray, G. A., DeLany, J. P., Volaufova, J., Harsha, D. W., \& Champagne, C. (2002). Prediction of body fat in 12-y-old African American and white children: evaluation of methods. American Journal of Clinical Nutrition, 76, 980-990. doi: 10.1093/ajcn/76.5.980.

5. Das, S. \& Bose, K. (2011). Prevalence of thinness using new international cut-off points among Santal tribal children and adolescents of Purulia District, West Bengal, India. Sri Lanka Journal of Child Health, 40(3), 105-110. doi: 10.4038/sljch.v40i3.3507.

6. de Onis, M., Blössner, M., \& Borghi, E. (2010). Global prevalence and trends of overweight and obesity among preschool children. American Journal of Clinical Nutrition, 92, 12571264. doi: 10.3945/ajen.2010.29786.

7. Debnath, S., Mondal, N. \& Sen, J. (2018). Percent of body fat, fat-mass, fat-free mass and assessment of body composition among rural school-going children of Eastern-India. Anthropological Review, 81(2), 158-173. doi: 10.2478/anre-2018-0011.

8. Deurenberg, P., Deurenberg-Yap, M., Foo, L. F., Schmidt, G., \& Wang, J. (2003). Differences in body composition between Singapore Chinese, Beijing Chinese and Dutch children. European Journal of Clinical Nutrition, 57, 405-409. doi: 10.1038/sj.ejcn.1601569.

9. Dey, L., Biswas, R., Ray, K., Bhattacherjee, S., Chakraborty, M., \& Pal, P. P., (2011). Nutritional status of school going adolescents in a rural block of Darjeeling, West Bengal, India. The Health, 2, 75-77. doi: 10.4103/0975-9727.146414.

10. Dutta Chowdhury, S., Chakraborti, T., \& Ghosh, T. (2007). Fat patterning of Santhal children: a tribal population of West Bengal, India. Journal of Tropical Pediatrics, 53, 98-102. doi: 10.1093/tropej/fml065.

11. Eveleth, P. B., \& Tanner, J. M., (1990). Worldwide Variation in Human Growth. 2nd Edition. Cambridge: Cambridge University Press.

12. Freedman, D. S., Wang, J., Ogden, C. L., Thornton, J. C., Mei, Z., Pierson, R. N., ..., Horlick, M. (2007). The prediction of body fatness by BMI and skinfold thicknesses among children and adolescents. Annals of Human Biology, 34,183-194.

13. Freedman, D. S., Wang, J., Thornton, J. C., Mei, Z., Pierson, R. N. Jr., Dietz, W. H., \& Horlick, M. (2008). Racial/ethnic differences in body fatness among children and adolescents. Obesity, 16, 1105-1111.

14. Freedman, D. S., Horlick, M., \& Berenson, G. S., (2013). A comparison of the Slaughter skinfold-thickness equations and BMI in predicting body fatness and cardiovascular disease risk factor levels in children. American Journal of Clinical Nutrition, 98, 1417-1424. doi: 10.3945/ajcn.113.065961.

15. Garrow, J. S., \& Webster, J. (1985). Quetelet's index $\left(\mathrm{W} / \mathrm{H}^{2}\right)$ as a measure of fatness. International Journal of Obesity, 9, 147-153.

16. Gaskin, P. S., \& Walker, S. P. (2003). Obesity in a cohort of black Jamaican children as estimated by BMI and other indices of adiposity. European Journal of Clinical Nutrition, 57, 420-426. doi: 10.1038/sj.ejcn.1601564.

17. Going, S. B., Lohman, T. G., Cussler, E. C., Williams, D. P., Morrison, J. A., \& Horn, P. S. (2011). Percent body fat and chronic disease risk factors in U.S. children and youth. American Journal of Preventive Medicine, 41(suppl 2), S77-86. doi: 10.1016/j.amepre.2011.07.006. 
18. Gulliford, M. C., Mahabir, D. R. B., Rocke, B., \& Chinn, S. (2001). Overweight, obesity and skinfold thicknesses of children of African or Indian descent in Trinidad and Tobago. International Journal of Epidemiology, 30(5), 989-998. https://doi.org/10.1093/ije/30.5.989

19. Karri, B., Ghritlahre, M., Das, S., \& Bose, K. (2017). Nutritional status among children and adolescents aged 6-18 years of Kolam tribe of Andhra Pradesh, India. Anthropological Review, 80, 153-163. doi: 10.1515/anre-2017-0010.

20. Khadilkar, V. V. \& Khadilkar, A. V. (2019). Body composition of tribal Indian girls from the North East India. The Indian Journal of Pediatrics, 86(6), 492-493. doi: 10.1007/s12098019-02958-9.

21. Laurson, K. R., Eisenmann, J. C., \& Welk, G. J. (2011). Development of youth percent body fat standards using receiver operating characteristic curves. American Journal of Preventive Medicine, 41(suppl 2), S93-99. doi: 10.1016/j.amepre.2011.07.003.

22. Leitao, R., Rodrigues, L. P., Neves, L., \& Carvalho, G. S. (2011). Changes in adiposity status from childhood to adolescence: a 6-year longitudinal study in Portuguese boys and girls. Annals of Human Biology, 38, 520-528. doi: 10.3109/03014460.2011.571220.

23. Lohman, T. G., Roche, A. F., \& Martorell, R. (1988). Anthropometric Standardization Reference Manual. Chicago: Human Kinetics Books.

24. Malina, R., Bouchard, C., \& Beunen, G. (1988). Human growth on well-nourished children. Annual Review of Anthropology, 17, 187-219.

25. Mandal, G. C. \& Bose, K. (2017). Body composition of rural children aged 2-6 years of Bengalee Ethnicity from Arambag, West Bengal, India. Journal of Life Sciences, 9(1), 48- 54. https://doi.org/10.1080/09751270.2017.1336015.

26. Martorell, R., Kettel Khan, L., Hughes, M. L., \& Grummer-Strawn L. M. (2000). Overweight and obesity in preschool children from developing countries. International Journal of Obesity and Related Metabolic Disorders, 24(8), 959-967. doi: 10.1038/sj.ijo.0801264.

27. Maynard, L. M., Wisemandle, W., Roche, A. F., Chumlea, W. C., Guo, S. S. \& Siervogel, R. M. (2001). Childhood body composition in relation to body mass index. Pediatrics, 107(2), 344-350. doi: 10.1542/peds.107.2.344.

28. Mehdad, S., Hamrani, A., Kari, K. E., Hamdouchi, A. E., Barakat, A. El Mzibri, M., ...Aguenaou, H. (2012). Body Mass Index, Waist Circumference, Body Fat, Fasting Blood Glucose in a Sample of Moroccan Adolescents Aged 11-17 Years. Journal of Nutrition and Metabolism, 2012, 510458. doi: 10.1155/2012/510458.

29. Zimmermann M., B., Gübeli, C., Puntener, C., \& Molinari, L. (2004). Overweight and obesity in 6-12 years old children in Switzerland. Swiss Medical Weekly, 134, 523-528. doi: 2004/35/smw-10640.

30. Monyeki, K. D., van Lenthe, F. J., \& Steyn, N. P. (1999). Obesity: does it occur in African children in a rural community in South Africa? International Journal of Epidemiology, 28, 287-292. doi: 10.1093/ije/28.2.287.

31. Must, A., \& Anderson, S. E. (2006). Body mass index in children and adolescents: Considerations for population-based applications. International Journal of Obesity, 30, 590594. doi: 10.1038/sj.ijo.0803300.

32. Nikolova, M., Mladenova, S., Boyadzhiev, D., \& Paskaleva, T. (2019). Changes in body composition and skeletal robustness in 7-17-year-old children and adolescents from Plovdiv, Bulgaria (1998-2008). Anthropological Researches and Studies, 9, 41-53. doi: http://doi.org/10.26758/9.1.4.

33. Nwizu, S. E., Njokanma, O. F., Okoromah, C. A. N., \& David, A. N. (2014). Age and genderrelated fat mass index and fat- free mass index patterns among adolescents in Surulere LGA, Lagos. Nigerian Journal of Peadiarics, 41(2), 120-124. doi:10.4314/NJP.V41I2.8. 
34. Olhager, E., \& Forsum, E. (2003). Total energy expenditure, body composition and weight gain in moderately preterm and full term infants at term postconceptional age. Acta Paediatrica, 92(11), 1327-1334. https://doi.org/10.1111/j.1651-2227.2003.tb00504.x.

35. Orphanidou, C. J. (1994). Accuracy of subcutaneous fat measurement: comparison of skinfold calipers, ultrasound and computed tomography. American Dietetic Association, 94, 855-858. doi: 10.1016/0002-8223(94)92363-9.

36. Pal, A., Pari, A. K., Sinha, A., \& Dhara, P. C. (2017). Prevalence of under nutrition and associated factors: A cross-sectional study among rural adolescents in West Bengal, India. International Journal of Pediatrics and Adolescent Medicine, 4, 9-18. doi: 10.1016/j.ijpam.2016.08.009.

37. Patil, S. N., Wasnik, V., \& Wadke, R. (2009). Health Problems Amongst Adolescent Girls in Rural Areas of Ratnagiri District of Maharastra, India. Journal of Clinical and Diagnostic Research, 3, 1784-1790.

38. Pavlica, T., \& Rakic, R. (2019). Total body skeletal muscle mass in children and adolescents. Studii și Cercetari de Antropologie, 6, 45.

39. Prado Martinez, C., Marrodan Serrano, M. D., Acevedo Cantero, P., \& Carmenate Moreno, M. (2017). Girl Body Composition according to pubertal status. Methodology variation. Studii si Cercetari de Antropologie, 5, 73.

40. Rada, C. (2017). Spending leisure time, classification according to body mass index in a sample of young people in Romania. Studii si Cercetari de Antropologie, 5, 75.

41. Rakic, R., \& Pavlica T. (2014). Nutritional Status of 19-Year-Old Adolescents in Urban Areas of Vojvodina - The Republic of Serbia, Anthropological Researches and Studies, 4, 13-19.

42. Rajkumari, B., Akoijam, B. S., Akoijam J. S. \& Longjam, U. (2012). Assessment of body composition and body mass index of adolescent school children in Imphal-West district, Manipur. Journal of Medical Society, 26(3), 184-188. doi: 10.4103/0972-4958.113248.

43. Roche, A. F., Sievogel, R. M., Chumlea, W. C., \& Webb, P. (1981). Grading body fatness from limited anthropometric data. American Journal of Clinical Nutrition, 34, 2831-2838. doi: 10.1093/ajcn/34.12.2831.

44. Rolland-Cachera, M. F. (1993). Body composition during adolescence: method, limitation and determinants. Hormone Research in Paediatrics, 39(suppl 3), 25-40. https://doi.org/10.1159/000182782.

45. Roy, S., Barman, S., Mondal, N., \& Sen, J. (2016). Prevalence of stunting and thinness among adolescent girls belonging to the Rajbanshi population of West Bengal, India. Journal of Nepal Paediatric Society, 36(2), 147-155. doi: 10.3126/jnps.v36i2.14535.

46. Saha, S., \& Sil, S. K. (2019). A comparative study on fat pattern between tribal andnon-tribal girls of Tripura, north-east India. Indian Journal of Pediatrics, 86(6), 508-514. doi: 10.1007/s 12098-019-02879-7.

47. Sardinha, L. B., Going, S. B., Teixeira, P. J., \& Lohman, T. G. (1999). Receiver operating characteristic analysis of body mass index, triceps skinfold thickness, and arm girth for obesity screening in children and adolescents. American Journal of Clinical Nutrition, 70, 1090-1095. doi: 10.1093/ajcn/70.6.1090.

48. Sharma, J., \& Mondal, N. (2018). Physical growth and body composition assessment among rural adolescent girls (10-16 years) of Karbi Anglong, Assam, Northeast India. Journal of Life Science, 10, 16-28. doi: 1.258359/KRE-39.

49. Slaughter, M. H., Lohman, T. G., Boileau, R., Horswill, C. A., Stillman, R. J., ... Bemben, D. A. (1988). Skinfold equations forestimation of body fatness in children and youth. Human Biology, 60(5), 709-723.

50. Steinberger, J., Jacobs, D. R., Raatz, S., Moran, A., Hong, C. P., \& Sinaiko, A. R. (2005). Comparison of body fatness measurements by BMI and skinfolds vs dual energy X-ray 
absorptiometry and their relation to cardiovascular risk factors in adolescents. International Journal of Obesity, 29, 1346-1352. doi: 10.1038/sj.ijo.0803026.

51. Tanner, J. M. (1962). Growth at Adolescence (2nd Eds.). Oxford: Blackwell Scientific Publications.

52. Troiano, R. P., Flegal, K. M., Kuczmarski, R. J., Campbell S. M., \& Johnson, C. L. (1995). Overweight prevalence and trend for children and adolescents. The National Health and Nutrition Examination Surveys 1963 to 1991. Archives of Pediatrics and Adolescent Medicine, 149, 1085-1091. doi: 10.1001/archpedi.1995.02170230039005.

53. Ulijaszek, S. J., \& Kerr, D. A. (1999). Anthropometric measurement error and the assessment of nutritional status. British Journal of Nutrition, 82, 165-177. https://doi.org/10.1017/S0007114599001348.

54. Vague, J. (1956). The degree of masculine differentiation of obesities: a factor determining predisposition to diabetes, atherosclerosis, gout and uric calculous disease. American Journal of Clinical Nutrition, 4, 20 -34. doi: 10.1093/ajcn/4.1.20.

55. Van Itallie, T. B., Yang, M. U., Heymsfield, S. B., Funk, R. C., \& Boileau, R. A. (1990). Height normalized indices of the body's fat free mass and fat mass: Potentially useful indicators of nutritional status. American Journal of Clinical Nutrition, 52(6), 953-959. doi: 10.1093/ajen/52.6.953.

56. Wells, J. C. (2007). Sexual dimorphism of body composition. Best Practice \& Research Clinical Endocrinology \& Metabolism, 21(3), 415-430. doi: 10.1016/j.beem.2007.04.007.

57. Yoo, S., Lee, S. Y., Kim, K. N, \& Sung, E. (2006). Obesity in Korean pre-adolescent school children: comparison of various anthropometric measurements based on bioelectrical impedance analysis. International Journal of Obesity, 30, 1086-1090. doi:10.1038/sj.ijo.0803327.

58. ***World Health Organization. (1995). Physical Status: The Use and Interpretation of Anthropometry: Technical report No. 854. Geneva: WHO. 